\title{
PENINGKATAN HASIL BELAJAR SISWA MELALUI METODE DRILL MATERI OPERASI HITUNG BILANGAN BULAT DAN PEMECAHAN MASALAH PADA MATA PELAJARAN MATEMATIKA DI KELAS V SDN 165726 TEBING TINGGI
}

\author{
Sutiah \\ Surel: sutiah.guru@gmail.com
}

\begin{abstract}
This aim of this research is to improve learning result on mathematic subject through drill method. This classroom action research conducted by 2 cycles of the four phases: planning, implementation, observation, reflection. The subjects were students from class IV, SD Negeri 165726 Tebing Tinggi which amounted to 37 students. This study used a qualitative descriptive analysis technique. The results showed that the use of the problem posing method of mathematic subjects can improve student learning result characterized by increased mastery learning students, namely the first cycle (70,27\%), cycle II $(89,18 \%)$ and complete learn the clasical equal to $89,18 \%$.
\end{abstract}

Key word : Drill, Learning Result, Mathematic

\begin{abstract}
ABSTRAK
Penelitian ini bertujuan untuk meningkatkan hasil belajar siswa mata pelajaran Matematika melalui metode drill. Penelitian tindakan kelas ini dilaksanakan sebanyak 2 siklus dengan empat tahapan yaitu: perencanaan, pelaksanaan, observasi, refleksi. Subjek penelitian ini adalah siswa kelas IV SD Negeri 165726 Tebing Tinggi sebanyak 37 siswa. Penelitian ini menggunakan teknik analisis dekriptif kualitatif. Hasil penelitian menunjukkan bahwa penggunaan metode drill mata pelajaran matematika dapat meningkatkan hasil belajar siswa yang ditandai dengan peningkatan ketuntasan belajar siswa, yaitu siklus I $(70,27 \%)$, siklus II $(89,18 \%)$ dan dinyatakan berhasil secara klasikal 89,18\%.
\end{abstract}

Kata Kunci : Drill, Hasil Belajar, Matematika

\section{PENDAHULUAN}

Kemampuan berhitung

dikembangkan melalui mata pelajaran matematika di sekolah. Matematika merupakan salah satu mata pelajaran yang diajarkan di Sekolah Dasar. Matematika mempunyai peranan dalam melatih penalaran siswa. Melalui matematika diharapkan siswa dapat menerapkannya dalam kehidupan sehari-hari. Selain itu, matematika merupakan salah satu ilmu yang selalu berkembang, baik dari sisi materi maupun manfaatnya bagi masyarakat. Oleh karena itu, matematika penting untuk dikuasai sejak dini. Diharapkan apabila siswa dapat menguasai matematika dengan baik, siswa juga dapat menguasai ilmu-ilmu yang lain dengan baik pula. Belajar mengajar adalah suatu kegiatan yang bernilai edukatif. Nilai edukatif mewarnai interaksi yang terjadi antara guru dengan anak didik. Interaksi yang bernilai edukatif dikarenakan kegiatan belajar mengajar yang dilakukan, diarahkan 
untuk mencapai tujuan tertentu yang telah dirumuskan sebelum pengajaran dilakukan (Djamarah, 2002). Hasil belajar adalah hasil dari suatu interaksi dari tindakan belajar dan tindakan mengajar yang dilakukan oleh penyaji pembelajaran dan pembelajar (Abdurahman, 1999: $3)$.

Pembelajaran matematika di SD, matematika dipandang bukan untuk diajarkan oleh guru, tetapi untuk dipelajari oleh siswa. Siswa ditempatkan sebagai titik pusat pembelajaran matematika. setiap individu memerlukan kesempatan, perlakuan, dan fasilitas yang berbeda-beda dalam mempelajari matematika (Marsigit, 2011:9).

Guru bertugas menciptakan suasana, menyediakan fasilitas, dan lainnya, sedang peranan guru lebih bersifat sebagai manajer daripada pengajar. Pembelajaran dilakukan dalam suasana yang kondusif, yaitu suasana yang tidak begitu formal. Siswa mengerjakan kegiatan matematika yang berbeda-beda dengan target yang berbeda-beda. Guru memunyai tiga fungsi utama yaitu: sebagai fasilitator, sumber ajar dan pemonitor kegiatan siswa. Dengan demikian, guru dapat mengembangkan metode pembelajaran secara bervarisasi: ceramah, diskusi, pemberian tugas, seminar, dan sebagainya.

Berdasarkan survey awal yang telah dilakukan di SD Negeri 165726 Tebing Tinggi khususnya siswa kelas V, dapat dikatakan hasil belajar siswa relatif kurang memuaskan. Hal ini terbukti dari rendahnya rata-rata nilai ulangan harian siswa yaitu 68,3. Dari 37 siswa, hanya 20 siswa yang memenuhi nilai ketuntasan belajar (nilai 70) dan masih terdapat 17 siswa yang tidak memenuhi nilai ketuntasan. Sehingga presentase siswa yang lulus hanya $54,05 \%$ dan masih terdapat $45,94 \%$ siswa yang mendapat nilai dibawah nilai ketuntasan.

Sebagai solusi alternatif yang paling efektif dan efisien diantaranya adalah dengan melakukan penelitian tindakan kelas. Untuk dapat mengatasi masalah tersebut di atas, maka peneliti menerapkan metode drill. Metode drill atau latihan adalah suatu cara mengajar dengan memberikan latihan terhadap apa yang telah dipelajari peserta didik sehingga memperoleh suatu ketrampilan tertentu (Anitah, 2009:118). Dengan metode drill, siswa langsung dihadapkan kepada gambaran konkrit dari konsepkonsep abstrak pada mata pelajaran matematika. Siswa dibiasakan untuk memecahkan masalah matematika, secara berulang, sehingga siswa memahami dan memiliki keterampilan dalam pelajaran matematika.

Metode drill adalah suatu cara mengajar dimana siswa melaksanakan kegiatan-kegiatan latihan, agar siswa memiliki ketangkasan atau keterampilan yang 
lebih tinggi dari apa yang dipelajari (Ahmad, 1986:152).

Metode drill adalah satu kegiatan melakukan hal yang sama, berulang-ulang secara bersungguhsungguh dengan tujuan untuk memperkuat suatu asosiasi atau menyempurnakan suatu keterampilan agar menjadi bersifat permanen. Cirri khas dari metode ini adalah kegiatan berupa pengulangan yang berkalikali dari suatu hal yang sama (Sudjana, 2002:86).

Metode Drill and Practice biasanya digunakan dalam pembelajaran materi hitungan, bahasa asing dan peningkatan perbendaharaan kata-kata (vocabulary). Metode Drill and Practice ini mengarahkan siswa melalui latihan-latihan untuk meningkatkan kecekatan/ ketangkasan dan kefasihan/ kelancaran dalam sebuah keterampilan (Sharon, 2005:120).

Hal yang senada dengan pendapat di atas adalah Penelitian Utliya Hamida (2009) berjudul "Pengaruh Metode Drill Terhadap Prestasi Belajar Matematika Siswa Materi Bilangan Bulat Kelas IV SDI Al-Mubarok Kalidawir Tulungagung Tahun Ajaran 2009/2010". Dari penelitiannya membuktikan bahwa metode drill dapat berpengaruh terhadap prestasi belajar siswa. Peningkatan ini terlihat dari setelah penulis mengadakan penelitian diketahui bahwa metode drill dapat membuat siswa lebih memahami konsep operasi hitung pada bilangan bulat.

Berdasarkan permasalahan tersebut maka alternatif pendekatan pembelajaran yang tepat pada mata pelajaran matematika yaitu dengan metode drill. Melalui metode drill mengarahkan siswa melalui latihanlatihan untuk meningkatkan kecekatan/ketangkasan dan kefasihan/kelancaran dalam sebuah keterampilan.

Berdasarkan uraian pada latar belakang masalah, maka dapat dirumuskan permasalahan sebagai berikut: "Apakah dengan menggunakan pembelajaran metode drill meningkatkan hasil belajar matematika materi operasi hitung bilangan bulat di kelas IV SD Negeri 165726 Tebing Tinggi Tahun pelajaran 2013/2014?"

Tujuan dari penelitian ini adalah untuk meningkatkan hasil belajar matematika khususnya materi operasi hitung bilangan bulat pada siswa kelas V SD Negeri 165726 Tebing Tinggi tahun pembelajaran 2013/2014 melalui metode drill.

\section{METODE PENELITIAN}

Penelitian ini dilaksanakan pada bulan Oktober sampai dengan bulan November 2013 pada semester ganjil tahun ajaran 2013/2014. Penelitian ini dilaksanakan dalam 2 siklus. Peneliti mengambil lokasi penelitian tindakan kelas di SD Negeri 167644 Tebing Tinggi.

Subjek penelitian adalah siswa kelas V SD Negeri 165726 
Tebing Tinggi dengan jumlah siswa sebanyak 37 orang dengan 19 orang laki-laki dan 18 orang perempuan. Sumber data yang digunakan adalah siswa kelas V SD Negeri 165726 dan teman sejawat. Pada Penelitian tindakan kelas data yang dikumpulkan dapat berbentuk kuantitatif maupun kualitatif. Data kuantitatif yang berupa nilai dianalisis dengan menggunakan analisis deskriptif komparatif yaiu membandingkan nilai tes kondisi awal, nilai tes setelah siklus I dan II yaitu nilai dari hasil ulangan harian siswa kelas V SD Negeri 165726 pada siklus I dan II.

Metode penelitian yang digunakan dalam penelitian ini adalah Classroom Action Research atau penelitian tindakan kelas. Model penelitian tindakan kelas yang digunakan peneliti adalah sistem spiral refleksi diri yang dikembangkan oleh Kemmis dan Taggart yang dimulai dengan perencanaan, tindakan, pengamatan, dan refleksi. Masing-masing siklus terdiri dari dua kali pertemuan yaitu sebagai berikut;

Perencanaan

Pada tahapan ini dilakukan berbagai persiapan dan perencanaan tindakan yang meliputi: menyusun skenario pembelajaran berupa Rencana Pelaksaan Pembelajaran, mempersiapkan media pembelajaran dan alat observasi, dan membuat instrumen untuk evaluasi yang berupa soal tes tertulis. Selain mempersiapkan hal-hal tersebut, untuk dapat melaksanakan penelitian ini dengan tujuan yang jelas peneliti juga perlu menetapkan indikator ketercapaian dalam penerapan metode drill.

Pelaksanaan

\section{a. Siklus I}

Guru melakukan pembelajaran di dalam kelas dengan menggunakan panduan perencanaan yang telah dibuat. Siklus I dilakukan pada tanggal 8 November 2013. Pada kegiatan awal pembelajaran, guru membuka pelajaran dengan mengucapkan salam, menyampaikan tujuan pembelajaran, mengapersepsi kelas. Pada kegiatan inti pembelajaran, guru menjelaskan materi pelajaran tentang operasi hitung bilangan bulat, memberikan contoh-contoh soal operasi hitung bilangan bulat, memberikan latihanlatihan soal operasi hitung bilangan bulat, dan meminta siswa untuk mengerjakan soal. Pada kegiatan akhir, guru memberikan evaluasi dan memberikan motivasi kepada siswa.

\section{b. Siklus II}

Guru melakukan pembelajaran di dalam Guru melakukan pembelajaran di dalam kelas dengan menggunakan panduan perencanaan yang telah dibuat. Siklus I dilakukan pada tanggal 15 November 2013. Pelaksanaan tindakan pada siklus II ini juga sama dengan siklus I namun mengalami perbaikan menuju lebih baik lagi. 


\begin{abstract}
Peneliti mulai melakukan kegiatan pembelajaran dengan mengucapkan salam dan mengajak siswa membaca doa sebelum belajar. Selanjutnya, peneliti membaca absensi untuk mengecek kehadiran siswa sekaligus berbasa-basi menanyakan kabar siswa dan kesiapan siswa untuk mempelajari materi Operasi Hitung Bilangan bulat. Peneliti melanjutkan dengan pemberian motivasi agar selama pelajaran berlangsung siswa dapat mengikuti pelajaran secara aktif dan tidak gaduh.
\end{abstract}

\section{Observasi/Pengamatan}

Guru/Peneliti sekaligus sebagai observator dibantu oleh dua orang Guru lainnya melakukan observasi/pengamatan terhadap semua kejadian pada PBM untuk dijadikan acuan dalam membuat catatan (Vignette) dan pengisian lembar observasi yang telah dibuat selama proses pembelajaran. Dalam kegiatan pembelajaran, peneliti melakukan pengamatan dengan pengambilan data hasil belajar dan kinerja siswa. Hal tersebut antara lain:

a. Kegiatan siswa selama kegiatan pembelajaran Matematika

b. Kreatifitas dan tugas siswa secara individu maupun kelompok.

\section{Refleksi}

Peneliti mengkaji, melihat dan mempertimbangkan hasil atau dampak dari tindakan yang dilakukan berdasarkan lembar pengamatan yang diisi oleh pengamat. Kegiatan pada tahap refleksi meliputi kegiatan menganalisis, memahami dan membuat kesimpulan berdasarkan hasil observasi setiap siklus. menemukan kelebihan dan kelemahan tindakan perbaikan pembelajaran. Hasil analisis data yang dilaksanakan pada tahap ini akan dipergunakan untuk menemukan kelebihan dan kelemahan diri dalam merancang dan melakukan tindakan sebagai acuan.

Instrumen yang digunakan dalam penelitian ini adalah pedoman observasi, test hasil belajar, dan wawancara. Data aktivitas belajar dan kendala yang dihadapi selama proses pembelajaran dikumpulkan melalui observasi (lembar observasi terlampir). Hal-hal yang akan diobservasi adalah kegiatan lisan, kegiatan metrik, kegiatan emosional. Data hasil observasi, dan data hasil wawancara yang jenis datanya berupa pernyataan-pernyataan, dianalisis dengan menggunakan teknik analisis statistik deskriptif.

Metode pengumpulan data penelitian ini adalah tertulis dan observasi. Penelitian ini dikatakan berhasil apabila siswa telah memperoleh nilai ketuntasan secara klasikal minimal $85 \%$ dari jumlah siswa dengan rumus sebagai berikut:

Persentase Ketuntasan klasikal = Jumlah siswa yang tuntas $\times 100 \%$ Jumlah siswa yang mengikuti tes 


\section{HASIL DAN PEMBAHASAN}

Berdasarkan observasi awal pada pra siklus, diketahui hasil belajar siswa pada pra siklus dalam memahami materi pelajaran agak sulit. Sebelum dilakukan metode drill pada saat pembelajaran, siswa yang aktif cenderung sedikit sedangkan lebih banyak didominasi oleh siswa yang kurang aktif dalam proses kegiatan belajar mengajar.

Tes awal dilaksanakan untuk mengetahui kemampuan dasar siswa pada materi yang diajarkan. Tes awal juga dilaksanakan untuk menentukan penelitian dapat dilanjutkan atau tidak, hal ini dapat dilihat dari hasil yang diperoleh dari tes awal adalah dari 37 siswa, hanya 20 siswa yang memenuhi nilai ketuntasan belajar (nilai 70) dan masih terdapat 17 siswa yang tidak memenuhi nilai ketuntasan. Sehingga presentase siswa yang lulus hanya $54,05 \%$ dan masih terdapat $45,94 \%$ siswa yang mendapat nilai dibawah nilai ketuntasan dengan nilai rata-rata adalah 68,3 .

Hasil penelitian tindakan kelas menunjukkan bahwa pengamatan yang dilakukan oleh mitra kolaborasi dan peneliti pada aktivitas guru dan siswa melalui penerapan metode drill pada mata pelajaran matematika kelas V SD Negeri 165726 Tebing Tinggi dapat dilihat pada tabel sebagai berikut:

\begin{tabular}{|c|c|c|c|}
\hline \multicolumn{3}{|c|}{ Peningkatan Hasil Belajar } & \multirow[b]{2}{*}{ Keterangan } \\
\hline $\begin{array}{l}\text { Pra } \\
\text { Siklus }\end{array}$ & Siklus I & $\begin{array}{l}\text { Siklus } \\
\text { II }\end{array}$ & \\
\hline 20 & 26 & 33 & $\begin{array}{l}\text { Jumlah Siswa } \\
\text { Lulus }\end{array}$ \\
\hline 54,05 & 71,08 & 89,18 & $\begin{array}{l}\text { Persentase } \\
\text { Ketuntasan } \\
\text { Belajar }(\%)\end{array}$ \\
\hline $\begin{array}{l}\text { Tidak } \\
\text { Tuntas }\end{array}$ & $\begin{array}{l}\text { Tidak } \\
\text { Tuntas }\end{array}$ & Tuntas & $\begin{array}{l}\text { Ketuntasan } \\
\text { Secara } \\
\text { Klasikal }\end{array}$ \\
\hline
\end{tabular}

Tabel Peningkatan Hasil Belajar Siswa Pra Siklus, Siklus I \& II

Berdasarkan pengamatan peneliti dari tindakan pra siklus, siklus I dan II terjadi peningkatan hasil belajar pada jumlah siswa dan persen ketuntasan belajar secara klasikal. Pembelajaran siklus I menggunakan metode drill menunjukkan adanya peningkatan hasil belajar siswa. Hasil analisis data nilai keterampilan siswa mengenai materi pelaran pada tes siklus I dan menunjukkan bahwa persentase hasil tes siswa yang belajar tuntas naik sebesar $18,1 \%$ dibandingkan dengan siklus I.

Hasil ulangan siklus I, siswa pada pelajaran matematika di kelas $\mathrm{V}$ masih tergolong kurang, yaitu memperoleh rata-rata 68,3, sedangkan Kriteria Kelulusan Minimal (KKM) yang harus dicapai siswa adalah 70. Dari 37 orang siswa yang mengikuti ujian pada pelajaran matematika hanya 26 orang siswa atau $71,08 \%$ yang berhasil mendapatkan nilai di atas nilai 70 . Hasil tersebut menunjukkan bahwa pada siklus pertama secara klasikal siswa belum tuntas belajar, karena 
siswa yang memperoleh nilai $\geq 70$ hanya sebesar $71,08 \%$ lebih kecil dari persentase ketuntasan yang dikehendaki yaitu sebesar $85 \%$. Sebanyak 26 orang siswa setelah dilakukan tes akhir siklus I hasil belajarnya meningkat. Hanya saja peningkatan yang terjadi belum optimal karena hasil belajar masih berada dalam kategori kurang dan indeks peningkatan hasil belajar masih berada dalam kategori rendah.

Pada siklus I, secara garis besar kegiatan belajar mengajar dengan metode pembelajaran drill dilaksanakan belum dengan baik, peran guru masih cukup dominan untuk memberikan penjelasan dan arahan, karena metode tersebut masih dirasakan baru oleh siswa. Pada dasarnya hambatan pada siklus I telah dapat diatasi dengan cukup baik. Hal ini terlihat dengan adanya peningkatan pada setiap indikator pencapaian yang telah ditetapkan dibandingkan pada kondisi awal. Persentase rata-rata aktivitas siswa telah dapat ditingkatkan dan penguasaan materi juga telah dapat memenuhi target pencapaian yang telah ditentukan sebelumnya. Selain itu dalam hal pengerjaan tugas, hasilnya sudah baik dari sebelumnya meskipun belum maksimal

Dengan penerapan metode drill dapat meningkatkan hasil belajar siswa kelas V SD Negeri 165726. Nilai yang masih rendah disebabkan karena siswa belum terbiasa dengan metode drill dan siswa perlu beradaptasi dengan metode tersebut. Hasil tersebut menggambarkan perlu adanya suatu tahapan selanjutnya untuk memperbaiki hasil belajar agar target yang diharapkan dapat tercapai. Untuk siklus II kegiatan mengerjakan latihan soal ini diharapkan semakin baik karena siswa sudah terlatih dan terampil untuk mengerjakan latihan-latihan soal yang berhulbungan dengan materi operasi hitung bilangan pecahan

Hasil ulangan siklus II, siswa pada pelajaran matematika di kelas $\mathrm{V}$ masih sudah tergolong baik, yaitu memperoleh rata-rata 73,51, sedangkan Kriteria Kelulusan Minimal (KKM) yang harus dicapai siswa adalah 70 . Dari 37 orang siswa yang mengikuti ujian pada pelajaran matematika sebanyak 33 siswa atau $71,08 \%$ yang berhasil mendapatkan nilai di atas nilai 70 . Hasil tersebut menunjukkan bahwa pada siklus kedua secara klasikal siswa sudah tuntas belajar, karena siswa yang memperoleh nilai $\geq 70$ hanya sebesar $89,18 \%$ lebih besar dari persentase ketuntasan yang dikehendaki yaitu sebesar $85 \%$. Aspek yang dianggap kurang merupakan suatu kelemahan yang terjadi pada siklus I dan akan dijadikan bahan kajian untuk refleksi dan revisi yang akan dilakukan pada siklus II.

Dengan mencermati data
hasil tes akhir siklus II, dapat
dinyatakan bahwa terjadi
peningkatan yang signifikan pada
hasil belajar. Hal tersebut didukung


berdasarkan jumlah siswa yang mengalami peningkatan hasil belajar. Sebanyak 33 orang siswa tuntas secara klasikal dari 37 siswa setelah dilakukan tes akhir siklus II hasil belajarnya meningkat. Siswa sudah semakin berani mengacungkan tangan terhadap hal yang belum dimengerti dan bersemangat mengkomunikasikan hasil kerja $\mathrm{Hal}$ ini menunjukkan bahwa pelaksanaan pembelajaran pada siklus II sudah lebih baik dari siklus I.

Hasil observasi kegiatan siswa sudah termasuk ke dalam kategori baik, berarti disini peneliti sudah mulai memilimalisir kekurangan sebelumnya. Kegiatan siswa dalam memecahkan masalah dalam kelompok, berdiskusi dengan teman sebangku, dapat berupa saling berbagai jawaban, mempresentasikan hasil diskusi dengan teman sebangkunya di depan kelas mengalami peningkatan dari siklus sebelumnya. Sehingga dianggap sudah cukup baik oleh peneliti dan pengamat.

Catatan lapangan diIbuat sehubungan dengan hal-hal yang terjadi selama pembelajaran namun tidak tercantum dalam pedoman observasi. Adapun catatan lapangan pada siklus 2 sebagai berikut:

a) Di dalam kelas keadaanya mulai tenang sebelum pelajaran dimulai.

b) Siswa terlihat nampak lebih antusias ketika diberikan tugas dibanding pada pertemuan sebelumnya. c) Dalam mengerjakan soal-soal latihan, siswa mulai lebih percaya diri untuk mengerjakan soal-soal latihannya sendiri.

d) Siswa semakin antusias iuntuk bertanya jika masih ada yang belum mereka fahami tentang materi yang sedang dipelajari.

e) Sebagian besar siswa sudah semakin terampil dalam mengerjakan soal-soal latihan tentang operasi hitung bilangan pecahan.

Pada siklus II, siswa telah memahami materi operasi hitung bilangan bulat. Sikap dan respon siswa mulai senang terhadap pembelajaran matematika dengan menggunakan metode drill. Oleh karena itu tidak perlu pengulangan siklus. Maka dari itu tidak perlu dilanjutkan ke siklus selanjutnya karena sudah dianggap berhasil dan memenuhi kriteria penilaian secara klasikal.

Dengan metode drill, menunjukkan dapat mengasah keterampilan kognitif, psikomotorik (keterampilan dan kecakapan melakukan perintah guru) dan afektif (kemauan menghargai orang lain). Walaupun secara umum program pembelajaran berhasil dan berjalan dengan baik, bukan berarti tidak ada tindak lanjut dalam penelitian ini, dilihat dari hasil evaluasi yang disesuaikan dengan standar minimum kelulusan. Hal ini sejalan dengan pendapat Djamarah (2010 :95) yang menyebutkan bahwa untuk metode drill juga baik untuk 
memperoleh suatu ketangkasan, ketepatan, kesempatan dan keterampilan

Dari kegiatan pembelajaran yang telah berlangsung dengan penerapan metode drill, maka tujuan pembelajaran yaitu untuk dapat mengatasi kesulitan belajar siswa dan siswa untuk lebih aktif, kreatif dalam proses belajar-mengajar. Pada kegiatan siklus kedua, menunjukkan bahwa tidak ada permasalahan dalam perumusan perencanaan tindakan (RPP). Hal tersebut sesuai dengan pendapat Sharon (2005:12) yang menyatakan bahwa metode Drill and Practice ini mengarahkan siswa melalui latihan-latihan untuk meningkatkan kecekatan/ ketangkasan dan kefasihan/ kelancaran dalam sebuah keterampilan

Berdasarkan hasil yang didapat dari setiap siklus proses pembelajaran yang optimal, hal ini ditunjukkan dengan meningkatnya penguasaan materi dan hasil belajar siswa. Oleh karena itu dapat disimpulkan bahwa proses pembelajaran dengan penerapan metode drill sangat sesuai dengan mata pelajaran matematika khususnya materi operasi hitun bilangan bulat. Maka dari itu, Penelitian Tindakan Kelas (PTK) ini bisa dikatakan berhasil karena hasil peningkatan proses pembelajarannya optimal.

Gambaran peningkatan ketuntasan belajar siswa mata pelajaran matematika materi operasi hitung bilangan bulat yang diperoleh setelah melakukan penelitian dengan menggunakan metode drill terlihat pada diagram berikut:

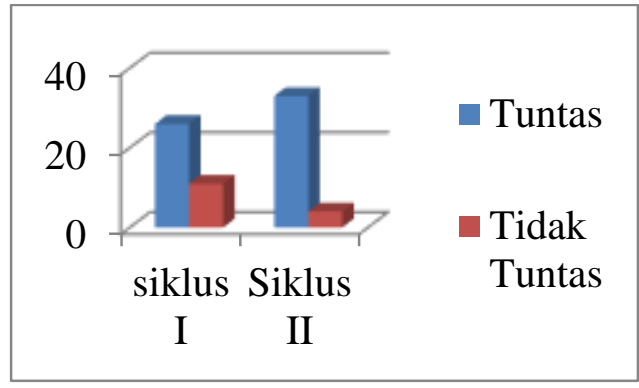

Grafik Peningkatan Ketuntasan Belajar

\section{KESIMPULAN}

Dari hasil temuan penelitian tentang hasil belajar siswa dengan metode drill di kelas V SD Negeri 165726 Tebing Tinggi tahun pelajaran 2013/2014 berdampak positif dalam meningkatkan hasil belajar siswa. Hal tersebut dapat dilihat dari peningkatan persentase ketuntasan belajar siswa pada siklus I $(71,08 \%)$ dan siklus II $(89,18 \%)$.

Atas dasar kesimpulan dan implikasi hasil penelitian tindakan kelas di atas, penulis memberikan saran-saran sebagai berikut:

a. Bagi Sekolah

Sekolah perlu memberikan dukungan kepada guru dalam menambah wawasan dan meningkatkan keterampilan dalam mengajar agar keberhasilan dalam proses pembelajaran di kelas tercapai. Dengan demikian guru akan mengetahui keberhasilan dan kekurangan pembelajaran yang telah dilakukannya. 
b. Bagi Guru

Guru harus mampu menguasai materi juga segala teknik mengajar sehingga ketika mengalami kendala akan dapat dicarikan jalan keluarnya sebagai alternatif lain serta lebih kreatif dalam merancang pembelajaran yang memberikan kesempatan kepada siswa untuk menemukan kembali pengetahuan.

c. Bagi Siswa

Siswa diharapkan untuk turut berperan aktif dalam proses pembelajaran di kelas serta menumbuhkan rasa ingin tahu yang lebih. Serta diharapkan mampu mengaktualisasi pengalaman belajar yang diperolehnya, dalam kehidupan sehari-hari.

\section{DAFTAR RUJUKAN}

Abdurrahman. 1999. Metode Pembelajaran Tindakan Kelas. Jakarta: Grafindo.

Ahmad, A. 1986. Metode Khusus

Pendidikan Agama.

Bandung: CV.Amrico.

Anitah, Sri. 2009. Teknologi Pembelajaran. Surakarta: Yuma Pustaka.

Djamarah, S. B dan A. Zaim. 2010. Strategi Belajar Mengajar. Jakarta : PT. Rineka Cipta.

Marsigit. 2011. Pengembangan Karakter dalam Pendidikan Matematika. Diakses dari http://www.academia.edu/22 29723/Implementasi_Pendid ikan_Karakter_dalam_Pendi dikan_Matematika. pada tanggal 18 Desember 2014, pukul 14.22 WIB.

Sharon. 2005. Instructional Technology and Media for Learning. Eighth Edition. Merril Prentice Hall.

Sudjana. 2002. Dasar-dasar Proses Belajar Mengajar.

Bandung: Sinar baru.

Utliya Hamida. 2009. Pengaruh Metode Drill Terhadap Prestasi Belajar Matematika Siswa Materi Bilangan Bulat Kelas IV SDI Al-Mubarok Kalidawir Tulungagung Tahun Ajaran 2009/2010.

Tulungagung
Skripsi. 